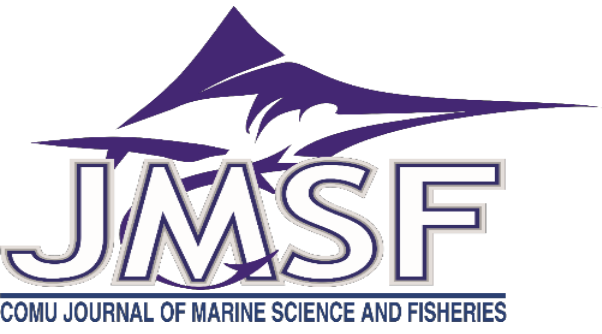

RESEARCH ARTICLE

\title{
The Effect of Different Solvents on Antioxidant Properties of Gongolaria barbata (Phaeophyceae)
}

\author{
Melis Yılmaz ${ }^{1}$, Gülen Türker², İlknur Ak ${ }^{3 *}$ \\ ${ }^{1}$ Çanakkale Onsekiz Mart University, School of Graduate Studies, Department of Fisheries Basic Sciences, Terzioğlu Campus, 17100, \\ Çanakkale/Turkey \\ ${ }^{2}$ Department of Food Technology, Faculty of Çanakkale Applied Sciences, Çanakkale Onsekiz Mart University, Terzioğlu Campus, 17100 \\ Çanakkale, Turkey \\ ${ }^{3 *}$ Çanakkale Onsekiz Mart University, Faculty of Marine Sciences and Technology, Department of Aquaculture, Terzioğlu Campus, 17100, \\ Çanakkale/Turkey \\ Correspondent: ilknurak@comu.edu.tr \\ Received: 10.11.2021 Accepted: 24.11.2021 \\ Melis Yllmaz: Orcid 0000-0002-8776-2117 \\ Gülen Türker: Orcid 0000-0002-7554-1544 \\ Ilknur Ak: Orcid 0000-0002-0233-0025
}

How to cite this article: Yılmaz, M., Türker, G., Ak, İ. (2021). The effect of different solvents on antioxidant properties of Gongolaria barbata (Phaeophyceae). COMU J. Mar. Sci. Fish, 4(2): 197-201. DOI: 10.46384/jmsf.1021387

Abstract: In this study, the antioxidant activities, total polyphenolic contents of algal extracts from Gongolaria barbata were examined by using ethyl acetate (AcOEt), water(W), and phosphate buffer (PH) as solvents. According to the results, EtOH, W, and PB showed medium antioxidant potential with low $\mathrm{IC}_{50}$ values. The highest total flavonoid content was detected in W $(6.91 \pm 0.09 \mathrm{mg} / \mathrm{g}$ Ext., and PB showed the maximum phenolic content (2.29 $\pm 0.01 \mathrm{mg} \mathrm{GAE} / \mathrm{g}$ ext.). The chlorophyll $a$ and total carotenoid contents were detected as $40.5 \pm 1.20$ and $29.13 \pm 1.12$ (mg/g DW), respectively. Phycoerythrin was $0.002 \pm 0.001$ (mg/g DW), while phycocyanin content was found as $0.04 \pm 0.01$ (mg/g DW). Our results show that PB could be used as an extraction solvent for determining the antioxidant properties of $G$. barbata instead of ethanol.

Key words: Antioxidant Properties, Brown Seaweed, Flavonoids, Gongolaria barbata, Phenolics

\section{Farklı Çözücülerin Gongolaria barbata'nın (Phaeophyceae) Antioksidan Özellikleri Üzerine Etkisi}

Özet: Bu çalışmada, Gongolaria barbata'dan elde edilen alg ekstraktlarının antioksidan aktiviteleri, toplam fenolik ve flavonoid içerikleri sırasıyla farklı çözücüler kullanılarak incelenmiştir: etil asetat (AcOEt), su(W) ve fosfat tamponu (PH). Sonuçlara göre EtOH, W ve PB çözücüleri, sirasıyla test edilen iki ticari antioksidan olan BHT ve Vitamin C'den önemli ölçüde daha yüksek olduğu ve düşük IC50 değerleri ile orta düzeyde antioksidan potansiyeli gösterdiği kaydedildi. En yüksek toplam flavonoid içeriği W (6.91 $\pm 0,09 \mathrm{mg} / \mathrm{g}$ Ext.) olarak tespit edildi ve PB en yüksek fenolik içeriği $(2.29 \pm 0.01 \mathrm{mg} \mathrm{GAE} / \mathrm{g}$ ext.) gösterdi. Klorofil a ve toplam karotenoid değerleri sırasıyla 40,5 $\pm 1,20$ ve $29,13 \pm 1,12$ (mg/g DW) olarak ölçüldü. Fikoeritrin $0.002 \pm 0.001$ (mg/g DW) olarak ölçülürken, fikosiyanin içeriği $0.04 \pm 0.01(\mathrm{mg} / \mathrm{g} \mathrm{DW})$ olarak bulundu. Çalışmamızın sonucuna göre, Gongolaria barbata'nın antioksidan içerikleri, toplam fenolik ve flavonoid içerikleri incelendiğinde, fosfat tamponunun etanolün yerine kullanılabilecek bir çözücü olduğu belirlenmiştir.

Anahtar kelimeler: Antioksidan Özellikleri, Fenolik, Flavonoid, Gongolaria barbata, Kahverengi Alg

\section{Introduction}

Marine macroalgae, also known as seaweed, are used in many industries, including cosmetics and pharmaceuticals, and they are also good candidates as raw materials for biofuel production due to high productivity (Ktari et al., 2021). Seaweeds are photosynthetic organisms with rich pigments and 
offer an excellent opportunity to the increasing global market demand for food coloring (Bizzaro et al., 2022). Besides their commercial use by the food industry, seaweeds are also rich in other biochemicals such as pigments, fatty acids, and polyphenols, which possess antioxidant, antibacterial, antitumor properties (Ślusarczyk et al., 2021). Especially, seaweeds from the Phaeophyceae family gained importance due to their high bioactive compounds in recent years. Gongolaria species are distributed in tropical and temperate waters (Guiry and Guiry, 2021). Perennial macroalgae attract the attention of researchers due to their phenol and polysaccharide contents. This seaweed contains alginic acid salts, polyunsaturated fatty acids, and minerals (Öztaşkent and $\mathrm{Ak}, 2021)$. The biochemical composition of $G$. barbata is affected by environmental factors such as temperature, salinity, and nutrient salts (Cirik et al., 2010).

Free radicals have a crucial role in affecting both human and animal health and cause many illnesses. In recent years, antioxidants have proven their applicability in preventing various diseases in which free radicals play a role (Devi et al., 2021). Many scientists have observed numerous antioxidants from unique elements of various plant species consisting of oilseeds, cereal plants, greens and spices (Banwo et al., 2021). Both terrestrial plants and seaweeds are rich resources of phytochemicals possessing essential properties, including antioxidants. Because seaweeds expose various abiotic and biotic stresses, they possess robust defence systems and produce critical secondary metabolites with pharmaceutical importance (Jégou et al., 2021). These metabolites are used in cancer, allergy, hypertension, oxidative stress and inflammation treatments, showing antimicrobial, antibacterial, and other pharmacological properties (Ślusarczyk et al., 2021).

The phenolic compounds increase the antioxidant capacity of photosynthetic organisms (Mildenberger et al., 2022). Seaweeds and plants contain phenolic compounds such as tannic acids, phenolic acids etc., which have many benefits for human health (Jégou et al., 2021; Bizzaro et al., 2022). Flavonoids are polyphenolic compounds and are known as safe and non-toxic antioxidants. Seaweeds' phenolic and flavonoid compounds change according to species, environmental conditions, and extraction solvents (Ak and Türker, 2019; Koru et al., 2021).

Besides the pharmaceutical and biomedical potentials of seaweed pigments in the last few years, they can be used as replacements for dyes/colorants (Wang et al., 2017). There has been a growing interest in natural pigments, especially in seaweeds. The primary pigments of seaweeds are chlorophylls, carotenoids and phycobiliproteins. In addition to chlorophyll $a$ pigment, brown algae also have chlorophyll $c$ pigment (Büchel, 2020). The carotenoids are found in the thylakoids of seaweeds, and they have a protective role against high irradiances. The light-harvesting complexes in these seaweeds are phycobiliproteins, which are mainly two components, phycoerythrin (red) and phycocyanin (blue) (Osório et al., 2020).

This study aimed to determine the antioxidant properties of algal extracts from $G$. barbata by using different solvents: water, ethyl acetate (AcOEt) and ethanol $(\mathrm{EtOH})$ phosphate buffer extracts.

\section{Material and Methods}

\section{Seaweed collection}

The thallus of Gongolaria barbata were collected, on March 2021, at low tide along the coast of Kilitbahir, Çanakkale, Turkey $\left(40^{\circ} 9^{\prime} 15^{\prime \prime N}\right.$; $26^{\circ} 22^{\prime} 38^{\prime \prime E}$ ) (Figure 1). The samples were transferred to the laboratory in ÇOMU. The samples were cleaned from epiphytes and other contaminants. Samples were dried at $30-35^{\circ} \mathrm{C}$ and stored for analysis.

\section{Extraction of the seaweed}

$1 \mathrm{gr}$ dried tallus of seaweed extracted with $10 \mathrm{ml}$ of 4 different solvents (water (W), ethyl acetate (AcOEt) and ethanol (EtOH) and phosphate buffer (PB) extracts) samples were kept in solvents for 24 hours. The samples were then filtered on filter paper.

\section{Determination of pigment contents}

The chlorophyll $a$ (chl $a)$, chlorophyll $c(\operatorname{chl} c)$ and total carotenoid (TCar), phycoerythrin (PE) and phycocyanin (PC) contents of samples were determined spectrophotometrically according to Jeffrey and Humphrey (1975) and Beer and Eshel (1985).

\section{DPPH radical scavenging activity}

The DPPH radical scavenging activity was determined according to Brand-Williams et al. (1995). Vitamin C and Butylated hydroxytoluene (BHT) were used as the control. The methanol and DPPH solutions were added to the extracts. The mixtures were left $30 \mathrm{~min}$ for the reaction, and then the absorbance value was determined spectrophotometrically. Nonlinear regression was used to calculate IC50 inhibition values.

\section{(TFC)}

Total phenolic (TPC) and flavonoid contents

Total phenolic and total flavonoid contents of $G$. barbata were found spectrophotometrically according to Djeridane et al.(2006) and Quettier-Deleu et al. (2000)

\section{Statistical analyses}

One-way analysis of variance (ANOVA) was used to determine the significance of differences between groups. Moreover, the correlations between the means were found with Pearson's correlation. 


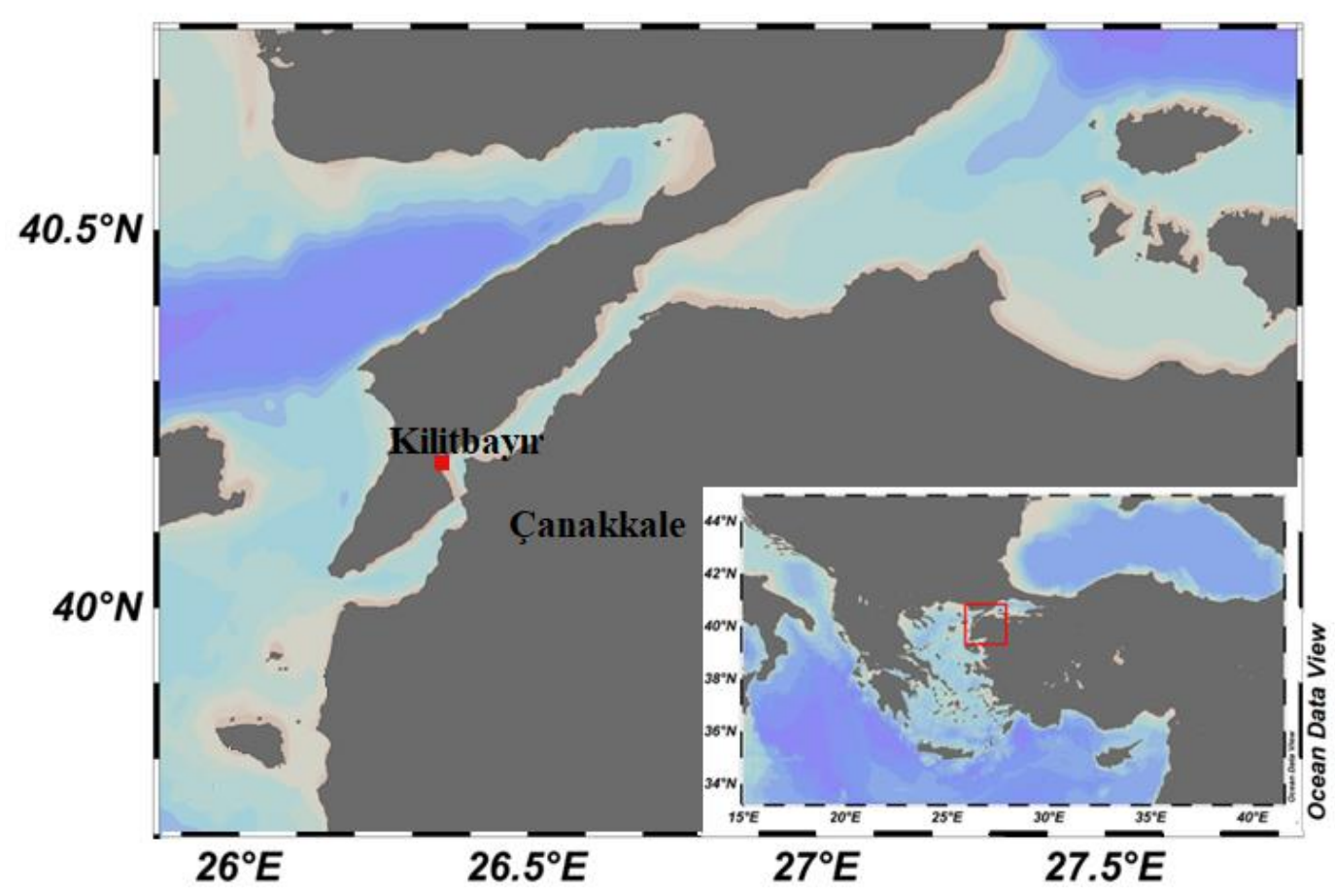

Figure 1. Sampling area

\section{Results and Discussion}

In this study, the antioxidant properties of four different seaweed extracts were evaluated (Table 1). AcOEt solvents showed the lowest antioxidant potential with a high $\mathrm{IC}_{50}(9.56 \pm 0.09 \mathrm{mg} / \mathrm{g}$ Ext. $)$. No significant differences were found between $\mathrm{W}, \mathrm{PB}$ and $\mathrm{EtOH}(\mathrm{p}>0.05)$, and these values are significantly higher than BHT and Vitamin $\mathrm{C}$, respectively. Ak and Türker (2019) reported that $\mathrm{IC}_{50}$ inhibition values of Eucheuma sp. and Laminaria sp. were found at $2.26 \pm 0.03$ to $2.63 \pm 0.03$, respectively. According to our results, EtOH, W and $\mathrm{PB}$ solvents were determined as the most suitable scavengers.

TPC and TFC contents of G. barbata extracts are shown in Table 2. It was found that all the groups were significantly different $(\mathrm{p}<0.05)$, and PB showed the highest phenolic potential $(2.29 \pm 0.01 \mathrm{mg} \mathrm{GAE} / \mathrm{g}$ ext.). The lowest value $(0.41 \pm 0.01 \mathrm{mg} \mathrm{GAE} / \mathrm{g}$ ext.) was found in the extract of AcOEt. Phenolics are one of the effective antioxidant sources, and they are dominant in seaweeds (Mildenberger et al., 2022). Mildenberger et al. (2022) and Zhu et al. (2022) reported that brown seaweed extracts changed phenolic content according to species.

The highest TFC was determined in W $(6.91 \pm 0.09$ $\mathrm{mg} / \mathrm{g}$ Ext.) (Table 2). The flavonoid contents of brown seaweeds varied according to species and environmental conditions (Mildenberger et al., 2022). Flavonoids play an essential role in seaweeds' defence systems, and they are associated with preventing vascular diseases and diabetes (Jégou et al., 2021). Also, they show antioxidant activity by chelation of metals (Shubina et al., 2021).
Table 1. $\mathrm{IC}_{50}$ inhibition values $(\mathrm{mg} / \mathrm{g}$ ext) and Inhibition rates $(\%)$ of $G$. barbata

\begin{tabular}{ccc}
\hline Solvents & $\begin{array}{c}\text { IC } \text { Co }_{50} \text { inhibition } \\
\text { values }\end{array}$ & Inhibition \\
\hline EtOH & $6.94 \pm 0.03^{\mathrm{b}}$ & $19.43 \pm 0.07^{\mathrm{b}}$ \\
$\mathrm{W}$ & $6.91 \pm 0.09^{\mathrm{b}}$ & $19.52 \pm 0.26^{\mathrm{b}}$ \\
$\mathrm{PB}$ & $6.96 \pm 0.10^{\mathrm{b}}$ & $19.40 \pm 0.28^{\mathrm{b}}$ \\
AcOEt & $9.56 \pm 0.09^{\mathrm{a}}$ & $14.20 \pm 0.13^{\mathrm{c}}$ \\
BHT & $1.40 \pm 0.01^{\mathrm{c}}$ & $99.00 \pm 0.01^{\mathrm{a}}$ \\
Vitamin c & $1.36 \pm 0.01^{\mathrm{c}}$ & $99.00 \pm 0.01^{\mathrm{a}}$ \\
\hline
\end{tabular}

Different superscripts in a column indicates statistical differences $(\mathrm{p}<0.05)$.

The chl $a, \operatorname{chl} c$, Tcar, PE and PC of G. barbata are shown in Table 3. The Chl $a$ and Tcar values were $40.5 \pm 1.20$ and $29.13 \pm 1.12 \quad(\mathrm{mg} / \mathrm{g} \quad \mathrm{DW})$, respectively. $G$. barbata is particularly rich in pigments and could be used as a powerful antioxidant source. Recent studies have shown that foods rich in carotenoids can reduce the risk of diseases such as cancer and heart disease (Jégou et al., 2021). and PC content are shown in Table 2. It was determined that PC content was higher than PE content. 
Table 2. The total phenolics (mg GAE/g ext.) and total flavonoids (mg rutin/g ext.) of $G$. barbata.

\begin{tabular}{ccc}
\hline Solvents & TFC & TFE \\
\hline EtOH & $1.67 \pm 0.01^{\mathrm{a}}$ & $1.14 \pm 0.02^{\mathrm{b}}$ \\
$\mathrm{W}$ & $1.69 \pm 0.01^{\mathrm{a}}$ & $1.01 \pm 0.01^{\mathrm{c}}$ \\
$\mathrm{PB}$ & $1.65 \pm 0.01^{\mathrm{a}}$ & $2.29 \pm 0.01^{\mathrm{a}}$ \\
$\mathrm{AcOEt}$ & $1.39 \pm 0.02^{\mathrm{b}}$ & $0.41 \pm 0.01^{\mathrm{d}}$ \\
\hline
\end{tabular}

Different superscript letters in a column indicates statistical differences $(\mathrm{p}<0.05)$
PE Besides chlorophyll $a$ which is mainly responsible for photosynthesis, seaweeds also contain other pigments such as carotenoids and phycobiliproteins (such as phycoerythrin and phycocyanin) (Osório et al., 2020). The phycobiliproteins, one of the groups of water-soluble compounds, are accessory pigments for photosynthetic light collection (Ak and Yücesan, 2012). In this study, for the first time, phycocyanin and phycoerythrin determinations were carried out in dry weights of brown algae. It has been determined that $G$. barbata contains these two pigments, albeit in small amounts.

Table 3. Chl $a$, Chl $c$, TCar, phycoerythrin and phycocyanin values of G. barbata (mg/g DW)

\begin{tabular}{ccccc}
\hline Chl $a$ & Chl $c$ & TCar & PE & PC \\
\hline $40.5 \pm 1.20$ & $8.66 \pm 0.45$ & $29.13 \pm 1.12$ & $0.002 \pm 0.001$ & $0.04 \pm 0.01$ \\
\hline
\end{tabular}

Correlation coefficient analysis results are shown in Table 3. Our results showed a negative correlation between DPPH scavenging activities and both flavonoids and phenolic values. In previous studies, the total phenolic and flavonoid were significantly correlated to $\mathrm{IC}_{50}$ inhibition values, and results show significant negative relationships (Ismail, 2017; Ak and Türker, 2019).

Table 4. Correlation coefficients $(n=9)$ between variables.

\begin{tabular}{ccc}
\hline & $\begin{array}{c}\text { IC }_{50} \text { inhibition } \\
\text { values }\end{array}$ & $\begin{array}{c}\text { Total } \\
\text { flavonoids }\end{array}$ \\
\hline Total phenolics & $-0.671^{*}$ & $0.609 *$ \\
Total flavonoids & $-0.987 *$ & \\
\hline
\end{tabular}

* Significant correlation at the 0.05 level.

\section{Conclusion}

Seaweeds are rich sources of chemical compounds having antibacterial, antioxidant, antitumor and other properties. As a result, increasing attention has been paid regarding the application of algae in the pharmaceutical, cosmetic, and food industries. Most of the studies that aim to determine antioxidant activities of polyphenolic compounds of seaweeds were carried out with methanol and ethanol as extracting solvents. According to the results of this study, phosphate buffer (PB) can be used as effective as methanol and ethanol solvents for determining antioxidant capacity, total phenolic and flavonoid contents of $G$. barbata. Also, in this study, phycoerythrin and phycocyanin contents of $G$. barbata were determined for the first time. At the end of the study, we found that the antioxidant activities and total polyphenolic contents of $G$. barbata show differences based on the solvent type. Extraction solvents of seaweeds used in primarily cosmetic and pharmaceutical industries should not be harmful to human and animal health and should be cheap and sustainable materials. From this point of view we suggest phosphate buffer for extraction solvent as well as ethanol.

\section{Acknowledgements}

Melis Y1lmaz is a PhD scholarship student in the council of higher education 100/2000 programme.

\section{Conflict of Interest}

There is no conflict of interest between the authors.

\section{Author Contributions}

M.Y., G.T. and I.A. contributed to concepts and design of experiments. M.Y. and G.T. have performed the experiments M.Y. and I.A. were carried out data analysis I.A. has responsibility for the integrity of the work and the correspondence.

\section{References}

Ak, İ., \& Türker, G. (2019). Antioxidant Activities of Eucheuma sp. (Rhodophyceae) and Laminaria sp. (Phaeophyceae). Turkish Journal of Agriculture Food Science and Technology, 7, 154-159. doi: 10.24925/turjaf.v7isp1.154-159.2791

Ak, İ., \& Yücesan, M. (2012). Effect of light intensity on the pigment composition of Gracilaria verrucosa (Rhodophyta). Fresenius Environmental Bulletin 21 (2), 337-342.

Banwo, K., Olojede, A. O., Adesulu-Dahunsi, A. T., Verma, D. K., Thakur, M., Tripathy, S., Singh, S., Patel, A. R., Gupta, A. K., Aguilar, C. N., \& Utama, G. L. (2021). Functional importance of bioactive compounds of foods with Potential Health Benefits: A review on recent trends. Food Bioscience, 43, $101320 . \quad$ doi: 10.1016/j.fbio.2021.101320 
Beer, S., \& Eshel, A. (1985). Determining phycoerythrin and phycocyanin concentrations in aqueous crude extracts of red algae. Marine and Freshwater Research, 36 (6), 785-792.

Bizzaro, G., Vatland, A.K., \& Pampanin, D.M. (2022). The one-health approach in seaweed food production. Environment International, 158:106948. doi: 10.1016/j.envint.2021.106948

Brand-Williams, W., Cuvelier, M. E., \& Berset, C. (1995). Use of a free radical method to evaluate antioxidant activity. LWT - Food Science and Technology, 28(1), 25-30. doi: 10.1016/S00236438(95)80008-5

Büchel, C. (2020). Light harvesting complexes in chlorophyll $c$-containing algae. Biochimica et Biophysica Acta (BBA) - Bioenergetics, 1861(4), 148027. doi: 10.1016/j.bbabio.2019.05.003

Cirik, Ş., Şen, E., \& Ak, İ. (2010). Brown algae Cystoseira barbata (Stackhouse) C. Agardh culture and changes in it chemical composition. Journal of fisheriessciences.com, 4(4), 354-361. doi:10.3153/jfscom.2010038

Devi, A., Dwibedi, V., \& Khan, Z. A. (2021). Natural antioxidants in new age-related diseases. Revista Brasileira de Farmacognosia, 31(4), 387-407. doi:10.1007/s43450-021-00175-0

Djeridane, A., Yousfi, M., Nadjemi, B., Boutassouna, D., Stocker, P., \& Vidal, N. (2006). Antioxidant activity of some algerian medicinal plants extracts containing phenolic compounds. Food Chemistry, 97(4), 654-660. doi:https://doi.org/10.1016/j.foodchem.2005.04.0 28

Guiry, M. D., \& Guiry, G. M. (2021). AlgaeBase. Access date: 07 October 2021, https://www.algaebase.org

Ismail, G. A. (2017). Biochemical composition of some Egyptian seaweeds with potent nutritive and antioxidant properties. Food Science and Technology, 37(2), 294-302. doi: 10.1590/1678$457 \times .20316$

Jeffrey, S. W., \& Humphrey, G. F. (1975). New spectrophotometric equations for determining chlorophylls $a, b, c_{1}$ and $c_{2}$ in higher plants, algae and natural phytoplankton. Biochemie und Physiologie der Pflanzen, 167(2), 191-194. doi: 10.1016/S0015-3796(17)30778-3

Jégou, C., Connan, S., Bihannic, I., Cérantola, S., Guérard, F., \& Stiger-Pouvreau, V. (2021). Phlorotannin and pigment content of native canopy-forming sargassaceae species living in intertidal rockpools in Brittany (France): Any relationship with their vertical distribution and phenology? Marine Drugs, 19(9), 504-524. doi: 10.3390/md19090504
Koru, E., Yilmaz, M., Turker, G., \& Ak, I. (2021). Antioxidant properties and element levels of two commercial Arthrospira strains. Phycologia. 60(sup1), 132-132. doi: $10.1080 / 00318884.2021 .1922050$

Ktari, L., Chebil Ajjabi, L., De Clerck, O., Gómez Pinchetti, J. L., \& Rebours, C. (2021). Seaweeds as a promising resource for blue economy development in Tunisia: current state, opportunities, and challenges. Journal of Applied Phycology. doi:10.1007/s10811-021-02579-w

Mildenberger, J., Stangeland, J.K., Rebours, C. (2022). Antioxidative activities, phenolic compounds and marine food allergens in the macroalgae Saccharina latissima produced in integrated multi-trophic aquaculture systems. Aquaculture,546(15): $737386 . \quad$ doi: 10.1016/j.aquaculture.2021.737386

Osório, C., Machado, S., Peixoto, J., Bessada, S., Pimentel, F. B., C. Alves, R., \& Oliveira, M. B. P. P. (2020). Pigments content (chlorophylls, fucoxanthin and phycobiliproteins) of different commercial dried algae. Separations, 7(2), 33. doi: 10.3390/separations 7020033

Öztaşkent, C. \& Ak, İ. (2021). Effect of LED light sources on the growth and chemical composition of brown seaweed Treptacantha barbata. Aquacult Int 29: 193-205 doi: 10.1007/s10499020-00619-9

Quettier-Deleu, C., Gressier, B., Vasseur, J., Dine, T., Brunet, C., Luyckx, M., Cazin, M., Cazin, J.-C., Bailleul, F., \& Trotin, F. (2000). Phenolic compounds and antioxidant activities of buckwheat (Fagopyrum esculentum Moench) hulls and flour. Journal of Ethnopharmacology, 72(1), 35-42. doi:https://doi.org/10.1016/S03788741(00)00196-

Ślusarczyk, J., Adamska, E., \& CzerwikMarcinkowska, J. (2021). Fungi and algae as sources of medicinal and other biologically active compounds: a review. Nutrients, 13(9), 3178. doi: 10.3390/nu13093178

Shubina, V.S., Kozina, V.I., \& Shatalin, Y.V. (2021). Comparison of antioxidant properties of a conjugate of taxifolin with glyoxylic acid and selected flavonoids. antioxidants, 10:1262. doi: 10.3390/antiox 10081262

Wang, H.-M. D., Li, X.-C., Lee, D.-J., \& Chang, J.-S. (2017). Potential biomedical applications of marine algae. Bioresource Technology, 244, 1407-1415. doi: 10.1016/j.biortech.2017.05.198

Zhu, X., Healy, L.E.i Sevindik, O., Sun, D., Selli, S. Kelebek, H., Tiwari, B.K. (2022). Impacts of novel blanching treatments combined with commercial drying methods on the physicochemical properties of Irish brown seaweed Alaria esculenta. Food Chemistry, 369(1): 130949. doi: 10.1016/j.foodchem.2021.130949 